\title{
Hatay ilindeki farklı lokasyonlarda yetiştirilen bazı çilek çeşitlerinin, derim süresi, aylık verim dağılımları ve toplam verim durumları
}

Distributions of total fruit yield, harvest period and monthly yield cultivated in different production places of some strawberry genotypes

\author{
Hakan ÖZBAY ${ }^{1}$ (D) Kazim GÜNDÜZ ${ }^{1}$
}

${ }^{1}$ Hatay Mustafa Kemal University, Faculty of Agriculture, Department of Horticulture, Antakya-Hatay, Turkey.

MAKALE BILGISI / ARTICLE INFO

Makale tarihçesi / Article history:

DOI: $10.37908 / \mathrm{mkutbd} .779170$

Geliş tarihi /Received:11.08.2020

Kabul tarihi/Accepted:07.10.2020

\section{Keywords:}

Strawberry, monthly yield, location, Antakya.

\footnotetext{
Corresponding author: Kazim GÜNDÜZ

$\bowtie:$ kazim.gunduz@ozal.edu.tr
}

Ö ZET / A BSTRACT

Atıf / Citation: Özbay H, Gündüz K (2020) Hatay ilindeki farklı lokasyonlarda yetiştirilen bazı çilek çeşitlerinin, derim süresi, aylık verim dağılımları ve toplam verim durumları. MKU. Tar. Bil. Derg. 25(3) : 499-508. DOI: 10.37908/mkutbd.779170

\section{GiRiş}

Çilek türleri kuzey yarım kürede yoğunlaşmış olmakla birlikte, dünyanın tarım yapılan hemen hemen bütün alanlarına yayılmıştır. Kültür çileği (Fragaria xananassa), oktoploid $F$. chiloensis ve $F$. virginiana türlerinin doğal melezlemesi sonucunda yaklaşık 300 yıl önce ortaya çıkmıştır (Staudt, 1989; Hancock, 1999). Ülkemizde çilek yetiştiriciliği giderek artmaktadır. Türkiye'de çilek yetiştiriciliğine 1970 'li yıllarda başlanmış ve hızlı bir artış görülmüştür. 1970 yılında 9.700 ton ürün üretilirken , 2019 yılında 486.705 ton ürün alınmıştır (TÜiK, 2020).
Ülkemizde yetiştiricilik sistemlerinin geliştirilmesi konusunda çalışmalar giderek önem kazanmaktadır. Islah programları son yıllarda özellikle yüksek verim, iri meyve, lezzet gibi kalite kriterleri üzerine yoğunlaşıldığı için piyasaya her geçen gün yeni çilek çeşitleri sunulmaktadır. Çilek dünyanın tarım yapılan tüm alanlarında; aynı ekolojilerde değişik zaman ve amaçlar için yetiştirilmesi nedeniyle tür içerisinde geniş çeşitlilik göstermektedir. Dünyanın birçok bölgesinde bu amaçlar doğrultusunda hareket eden Islah programları bulunmaktadır. Modern yetiştirme tekniklerinin uygulanması, yetiştiricilik şekillerinin çeşitlenmesiyle 
birlikte bu ıslah programları tarafından geliştirilen çeşitlerin bölgelere göre adaptasyon çalışmalarının yapılması gereklidir.

Ülkemizde çok sayıda adaptasyon çalışması yürütülmüştür. Bunlardan bazıları İştar ve ark., (1983), Erzurum koşullarında; Kaşka ve ark., (1979), Adana, Antalya, Aydın-Sultanhisar, Yalova, Ankara ve Dalaman'da ; Kaşka ve ark., (1986), Adana koşullarında; Kurnaz ve ark., (1992), Karadeniz bölgesinde Samsun, Çarşamba, Ordu ve Giresun'da; Gülsoy (2003), çalışmasını Van ekolojik şartlarında; İslam ve ark.,(2003), Ordu'nun Perşembe ilçesinde; Atasay ve ark., (2006), Isparta koşullarında yaptıkları çalışmada; Sabancı ve ark., (2007), Kahramanmaraş şartlarında; Sezer (2010), 2009-2010 yılları arasında Mardin ili Kızıltepe ilçesi örnek verilebilir. Gündüz (2003), 20002002 yılları arasında Amik ovasında ilk yıl 4 çilek çeşidini (Dorit, Camarosa, Selva ve Chandler) ikinci yılda Sweet Charlie çeşidini ekleyerek toplamda 5 çilek çeşidi kullanarak yüksek tünel ve açıkta yetiştiriciliğin ilk çiçeklenme ve ilk hasat tarihleri, hasat süresi, verim, erkencilik, kalite sınıfları ve meyve kalite özelliklerine etkisini incelemiştir. İki yılda elde ettiği sonuçlarına göre Amik Ovası koşullarında en erken çiçeklenmeyi yüksek tünelde Aralık ayı başlangıcı ve Aralık ayı sonunda, açıkta yetiştiricilikte ise Ocak ayının 1 . ve 3 . haftasında Sweet Charlie ve Selva çeşitlerinde elde etmiştir. Illk hasadına en erken yüksek tünelde Şubat ayının ilk haftasında, açıkta yetiştiricilikte mart ayının son haftasında başlamıştır. Bitki başına verimi ilk yıl yüksek tünelde yetiştiricilikte $600,8 \mathrm{~g} / \mathrm{bitki}$ ve açıkta yetiştiricilikte 655,4 g/bitki değerleri ile Camarosa çeşidinin en yüksek verim verdiğini tespit etmiştir.

Hatay yöresinde yetiştiricilik Mustafa Kemal Üniversitesi Ziraat Fakültesi tarafından yürütülen adaptasyon çalışmaları sonucunda 2019 yılı üretim miktarı 2.463 tona ulaşmıştır (Anonim, 2019). Yörede yetiştiricilik giderek artmaktadır. Sahip olduğu ekolojik koşullar dikkate alındığında Akdeniz Bölgesinin en güneyinde yer alan Hatay ilinde Amik ovası, Dörtyol-Erzin, Samandağ, İskenderun-Arsuz erkenci çilek yetiştiriciliği bakımından büyük bir potansiyele sahiptir. Bu konuda Amik ovasında hakim rüzgarlara karşı gerekli önlemler alındığında erkenci çilek yetiştiriciliğinin yapılabileceği bazı çalışmalar ile ortaya konmuştur (Özdemir ve ark., 2001; Gündüz, 2003; Özdemir ve Gündüz, 2004).

$\mathrm{Bu}$ çalışmada; üç farklı yetiştirme lokasyonunda (Antakya, Yayladağı ilçesinin Urumu ve Şakşak Mevkilerinde) bazı çilek çeşitlerinde derim süresi ve verim durumlarını belirlemek amaçlanmıştır.

\section{MATERYAL ve YÖNTEM}

Araştırma Mustafa Kemal Üniversitesi Ziraat Fakültesi Bahçe Bitkileri Bölümüne ait Araştırma ve Uygulama arazisi ile Hatay ili Yayladağı ilçesinde yürütülmüştür.

Deneme yaz dikim yöntemi ile frigo fide kullanılarak yapılmıştır. Bitkisel materyal olarak Rubygem ve Camarosa kısa gün ile Albion ve San Andreas gün-nötr çilek çeşitleri kullanılmıştır. Denemenin yürütüldüğü yetiştirme lokasyonlarına ait rakım ve koordinatlar Çizelge 1'de verilmiştir.

Çizelge 1. Araştırmanın yürütüldüğü lokasyona ait rakım ve koordinatlar

Table 1. Altitude and coordinates of the location where the study is conducted

\begin{tabular}{lll}
\hline Lokasyonlar & Rakım $(\mathrm{m})$ & Koordinatlar \\
\hline Üzümsü Meyveler Araştırma ve Uygulama Alanı (Antakya) & \multirow{2}{*}{117} & $36^{\circ} 13.413 \mathrm{~N}$ \\
& & $036^{\circ} 09.102 \mathrm{E}$ \\
Urumu Mevki (Yayladağı) & 443 & $35^{\circ} 54.589 \mathrm{~N}$ \\
& & $036^{\circ} 02.34 \mathrm{E}$ \\
Şakşak (Yayladağı) & 755 & $35^{\circ} 58.112 \mathrm{~N}$ \\
\hline
\end{tabular}

Fide dikimi açıkta yetiştiricilik sisteminde siyah plastikle malçlanmış masuralar üzerinde yapılmıştır. Masuralar dekara 3 ton hesabıyla yanmış çiftlik gübresi ile gübrelenmiştir. Gübreler aylık olarak (15 kg da ${ }^{-1} \mathrm{~N}$ tüm vejetasyon boyunca $\mathrm{NH}_{4}\left(\mathrm{SO}_{4}\right)_{2}$ damla sulama ile verilmiştir. Kloroza karşı ise $0.5-1 \mathrm{~g} /$ bitki sequestrene $\mathrm{Fe}$ 138 kullanılmıştır. Dikimler ağustos ayı içinde gerçekleştirilmiştir. Bitkiler çapraz dikim yöntemiyle dikilmiştir. Sulama, damla sulama şeklinde yapılmıştır. Yetiştirme lokasyonlarına ait toprak özelliklerini belirlemek amacıyla toprak örnekleri deneme alanlarını temsil edecek şekilde $0-30 \mathrm{~cm}$ derinlikten alınmıştır (Çizelge 2). 
Çizelge 2. Lokasyonların toprak özellikleri

Table 2. Soil properties of locations

\begin{tabular}{lllllllllllllll}
\hline Lokasyon & $\begin{array}{l}\text { Satürasyon } \\
(\%)\end{array}$ & Tuzluluk & $\mathrm{pH}$ & $\begin{array}{l}\text { Kireç } \\
(\%)\end{array}$ & $\begin{array}{l}\text { Organik } \\
\text { Madde } \\
(\%)\end{array}$ & $\begin{array}{l}\mathrm{P} \\
\left(\mathrm{kg} \mathrm{d}^{-1}\right)\end{array}$ & $\begin{array}{l}\mathrm{K} \\
\left(\mathrm{kg} \mathrm{d}^{-1}\right)\end{array}$ & $\begin{array}{l}\mathrm{Ca} \\
\left(\mathrm{kg} \mathrm{d}^{-1}\right)\end{array}$ & $\begin{array}{l}\mathrm{Mg} \\
\left(\mathrm{kg} \mathrm{d}^{-1}\right)\end{array}$ & $\begin{array}{l}\mathrm{Fe} \\
\mathrm{ppm}\end{array}$ & $\begin{array}{l}\mathrm{Cu} \\
\mathrm{ppm}\end{array}$ & $\begin{array}{l}\mathrm{Mn} \\
\mathrm{ppm}\end{array}$ & $\begin{array}{l}\mathrm{Zn} \\
\mathrm{ppm}\end{array}$ \\
\hline Antakya & 55 & 0.21 & 8.1 & 1.1 & 1.07 & 1.43 & 25.1 & 2493.8 & 509.6 & 125.8 & 1.62 & 6.0 & 0.51 \\
Şakşak & 68.5 & 0.40 & 7.9 & 2.49 & 1.94 & 1.88 & 222.5 & 4847.5 & 468.1 & 480.8 & 17.5 & 42.3 & 3.63 \\
Urumu & 49 & 0.19 & 7.9 & 2.8 & 0.91 & 1.31 & 54.5 & 4557.0 & 476.4 & 91.2 & 5.6 & 20.6 & 1.03 \\
\hline
\end{tabular}

Yetiştirme lokasyonlarına ait (Antakya, Şakşak ve Urumu) sıcaklık değerleri maksimum, minimum ve ortalama sıcaklık olarak alınmıştır (Şekil 1, 2 ve 3). Ölçümlere ekim ayı başında başlanmış olup haziran ayı sonuna kadar devam edilmiştir. Sıcaklık değerleri taşınabilir Testo marka Dijital Hava Kaydedici - Data Logger cihazı kullanılmış ve saatte bir değerler kaydedilmiştir. Lokasyonlar arasında maksimum sıcaklıklar Antakya'da haziran ayında $49.5{ }^{\circ} \mathrm{C}$, minimum sıcaklılar ise Şakşak lokasyonunda ocak ayında $-4.5{ }^{\circ} \mathrm{C}$ olarak kaydedilmiştir. Ortalama sıcaklık değerleri yine haziran ayında Antakya'dan $\left(25.9^{\circ} \mathrm{C}\right)$ alınırken en düşük ortalama sıcaklık değerleri Şakşak lokasyonundan (5.4 ${ }^{\circ} \mathrm{C}$ ) alınmıştır (Şekil 3). Yetiştirme dönemi boyunca donlu geçen gün sayısı Antakya ve Urumu lokasyonlarında 4, Şakşak'ta 8 gün olarak belirlenmiştir.

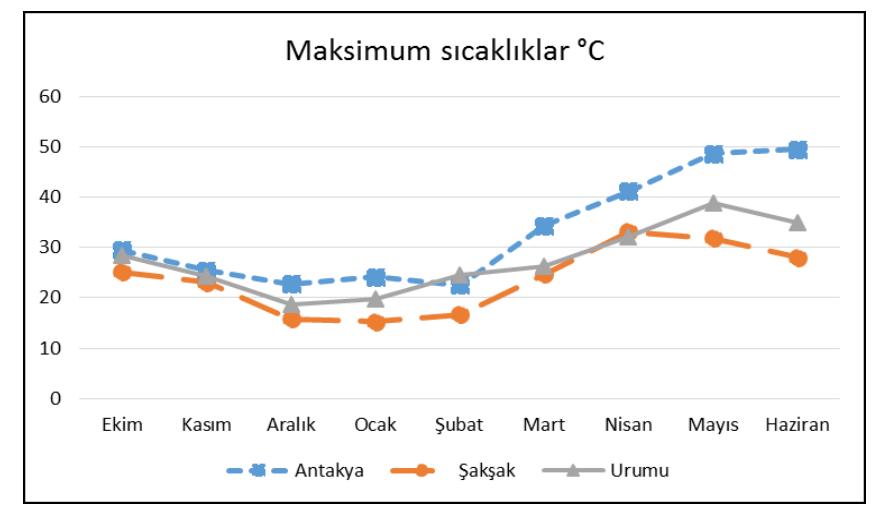

Şekil 1. Lokasyonlara göre maksimum sıcaklık değerleri $\left({ }^{\circ} \mathrm{C}\right)$

Figure 1. Maximum temperature values according to locations $\left({ }^{\circ} \mathrm{C}\right)$

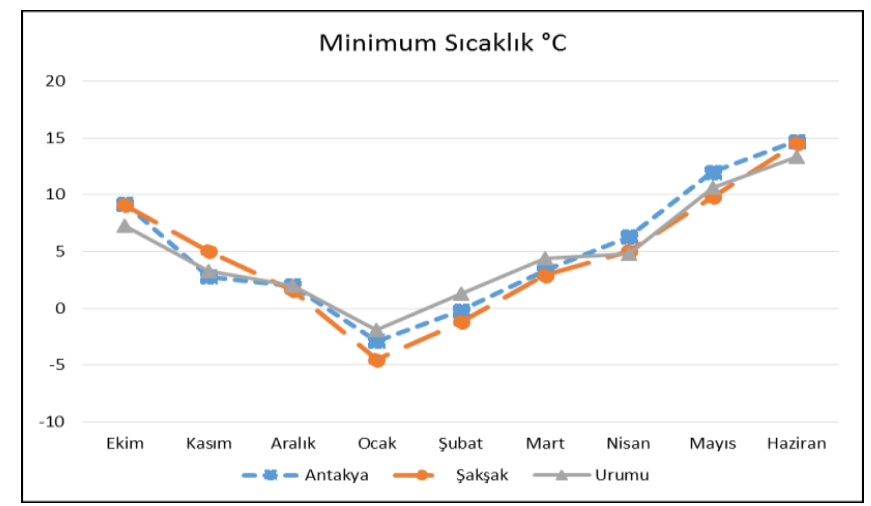

Şekil 2. Lokasyonlara göre minimum sıcaklık değerleri $\left({ }^{\circ} \mathrm{C}\right)$

Figure 2. Minumum temperature values according to locations $\left({ }^{\circ} \mathrm{C}\right)$ 


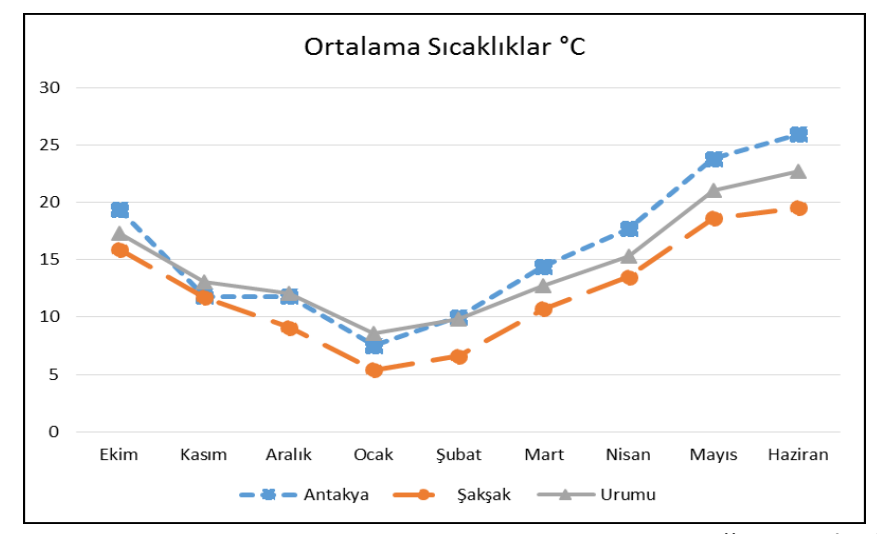

Şekil 3. Lokasyonlara göre ortalama sıcaklık değerleri $\left({ }^{\circ} \mathrm{C}\right)$

Figure 3. Average temperature values according to locations $\left({ }^{\circ} \mathrm{C}\right)$

Fidelerin ilk derim tarihleri ve derim süreleri (gün), genotipler ve yetiştirme lokasyonlarına göre düzenlenmiştir. Aylık verimler her ay derim yapılan meyvelerin tartılarak bitki sayısına bölünmesiyle (g/bitki) hesaplanmıştır. Bitki başına verimler $\mathrm{g} / \mathrm{bitki}$ olarak sunulmuştur.

\section{Deneme Deseni ve Istatistik Analiz}

Deneme tesadüf blokları deneme desenine göre üç lokasyonunda dört yinelemeli ve her yinelemede 20 bitki olacak şekilde düzenlenmiştir. Varyans analizleri SAS (2005) paket programı ile yapılmış olup, çoklu karşılaştırmalar 'Duncan Testi' ile değerlendirilmiştir.

\section{BULGULAR ve TARTIŞMA}

Deneme, çileklerde çeşit ve lokasyonun ilk derim ve verim parametrelerine etkisini araştırmak amacıyla yapılmıştır. Dolayısıyla ilk derim tarihi, derim süresi (gün), verimin aylara dağılımı ve bitki başına toplam verimler ( $\mathrm{g} / \mathrm{bitki})$ incelenmiş elde edilen bulgular aşağıda ayrı başlıklar halinde verilmiştir.

\section{ilk Derim Tarihleri}

Illk derimler en erken 2-4 Nisan tarihlerinde Antakya lokasyonunda Albion ve San Andreas çeşitlerinde yapılmıştır. Bunu 6-7 Nisan tarihleri ile yine Antakya lokasyonu Camarosa ve Rubygem çeşitleri izlemiştir. Urumu ve Şakşak lokasyonularında ise ilk derimler nisan ayının son haftasında Albion ve San Andreas çeşitlerinde yapılmıştır (Şekil 4).

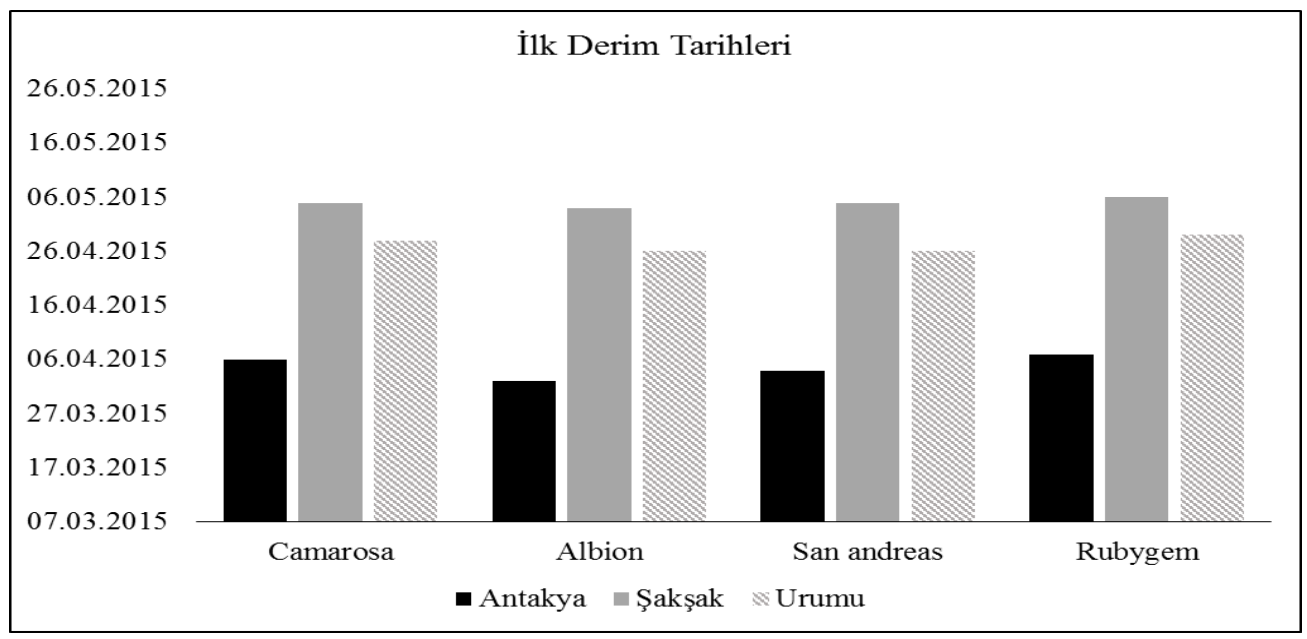

Şekil 4. Farklı lokasyonlarda yetiştirilen çilek çeşitlerine ait ilk derim tarihleri Figure 4. The first harvest dates of strawberry cultivars grown in different locations

Alata ve Adana'da yüksek tünelde yaz dikim yöntemleriyle yapılan çalışmalarda çeşitlere bağlı olarak ilk derimlere genellikle şubat ayında başlandığı ortaya konmuştur (Özdemir ve Kaşka, 1996; Türemiş ve ark., 1997). Amik Ovası koşullarında yürütülen diğer bir çalışmada ise ilk derimlere en erken şubat ayında Sweet 
Charlie çeşidinde başlanmıştır (Gidemen, 2003). Bizim çalışmamızda Antakya lokasyonunda ilk derimler Şakşak ve Urumu lokasyonundan bir miktar daha önce yapılmış olup, Amik ovasında yürütülen önceki çalışmalardan ise bir miktardaha geç derim yapıldığı görülmüştür. Bu durum araştırmanın yürütüldüğü yetiştirme döneminin ekolojik farklılı̆ından kaynaklanmaktadır. Urumu ve Şakşak lokasyonularında ise ilk derimler nisan ayının son haftasında yapılmıştır. Bu bulgular Özdemir ve ark., (2003)'ün Yayladağı'nda 9 çilek çeşidi ile açıkta yürütülen çalışmada ilk derimlerin nisan ayı ortalarında alındığı bulguları ile paralellik içerisindedir.

\section{Derim Süresi}

Lokasyonlar ve çeşitlere göre derim süreleri belirlenmiş ve Şekil 5'de verilmiştir. Çeşitler arasında en uzun derim süresi Şakşak lokasyonunda San Andreas çeşidinden (78 gün) alınmıştır. En kısa derim süresi Urumu lokasyonunda Rubygem çeşidinden (42 gün) alınmıştır. Lokasyonların derim süreleri bakımından Şakşak lokasyonu en uzun derim süresine sahip olmuş ve onu Antakya ve Urumu lokasyonları takip etmiştir (Şekil 5). Derim süreleri çeşitler ve lokasyonalara göre 42-78 gün arasında değişim göstermiştir. Çeşitlerden en uzun derim süresi "San Andreas" çeşidinden alınmışır. Lokasyonlardan en uzun derim süresi Şakşak'ta belirlenmiştir. Bu sonuçlar derim süresi üzerinde çeşit ve lokasyonun etkisini göstermektedir. Önal (2000), Menemen koşullarında yüksek tünel ve açıkta yaptığı çalışmada derim sürelerinin 40-60 günlük bir periodu içerdiğini, Gündüz (2003) ise Amik Ovası koşullarında yüksek tünel ve açıkta frigo fide kullanarak beş çilek çeşidiyle yaptığı çalışmada derim sürelerinin yetiştirme yerleri, çeşitler ve yıllara göre 73-130 gün arasında değişim gösterdiğini, çeşitlerden en uzun derim süresinin Selva ve Sweet Charlie'den alındığını, yüksek tünel yetiştiriciliğinin açıkta yetiştiriciliğe göre daha uzun derim süresine sahip olduğunu bildirmiştir. Saraçoğlu (2013), Kazova (Tokat) koşullarında bazı günnötr (Fern ve Kabarla) ve kısa gün (Camarosa, Sweet Charlie, Rubygem ve Festival) çilek çeşitlerini frigo fide kullanarak yaptığı çalışmada derim sürelerini 16-87 gün olarak belirlemiştir. Çalışmamızda derim süreleri 42-78 gün olarak belirlenmiş olup yürütülen önceki çalışmalardan bir parça farkıı olması ekolojik koşulların ve kullanılan çeşitlerin farklılığı ile açıklanabilir.

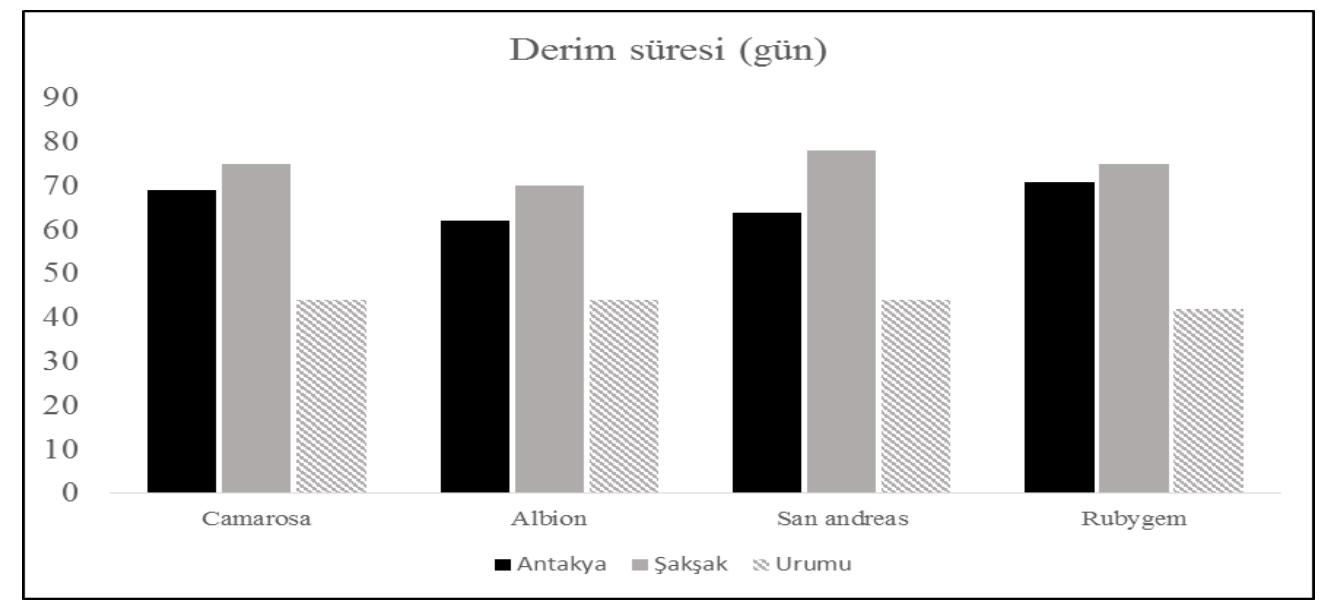

Şekil 5. Farklı lokasyonlarda yetiştirilen çilek çeşitlerine ait derim süreleri Figure 5. The harvest times of strawberry cultivars grown in different locations

\section{Aylık Verim Dağılımı (g/bitki) \\ Antakya lokasyonunda yetiştiricilik}

Antakya lokasyonunda yetiştirme dönemi boyunca alınan bitki başına aylık verimler Çizelge 3'de verilmiştir. Aylık verim değerleri ile yapılan varyans analizleri sonucunda nisan ve mayıs aylarında istatistiksel olarak farklılık belirlenmemiş olup, haziran ayında aylık verimler arasında önemli farklılıklar görülmüştür.

Nisan ayında aylık verimler arasında istatistiksel olarak fark belirlenmemiş olup, en yüksek verim $289.4 \mathrm{~g} /$ bitki ile Rubygem çeşidinden alınırken, en düşük verim ise
$155.4 \mathrm{~g} /$ bitki ile Albion çeşidinden alınmıştır. Mayıs ayında bitki başına aylık verimler düşmüş olmakla birlikte en yüksek verimi $104.6 \mathrm{~g} /$ bitki ile Camarosa çeşidi vermiş ve onu Rubygem çeşidi $101.7 \mathrm{~g} /$ bitki ile takip etmiştir. Mayıs ayındaki en düşük aylık verimi Albion çeşidi (39.6 g/bitki) vermiştir. Haziran ayında ise en yüksek aylık verim Rubygem çeşidinden (141.5 $\mathrm{g} /$ bitki) elde edilmiştir. Bu ayda en düşük aylık verimi Albion çeşidi (52.0 g/bitki) vermiştir. Antakya lokasyonunda aylık verimler değerlendirildiğinde Albion çeşidi düşük verimli olarak saptanmıştır. Rubygem ve 
Camarosa çeşitlerinin ise iyi düzeyde olduğu görülmüştür.

Çizelge 3. Antakya lokasyonuna ait aylık verimler (g/bitki)

Table 3. Monthly yields of Antakya location

\begin{tabular}{lccc}
\hline \multirow{2}{*}{ Çeşit } & \multicolumn{3}{c}{ Aylar } \\
\cline { 2 - 4 } & Nisan $^{\mathrm{x}}$ & Mayıs $^{\mathrm{y}}$ & Haziran $^{\mathrm{z}}$ \\
\hline Camarosa & 244.3 & 104.6 & $128.1 \mathrm{a}$ \\
Rubygem & 289.4 & 101.7 & $141.5 \mathrm{a}$ \\
Albion & 155.4 & 39.6 & $52.0 \mathrm{~b}$ \\
San Andreas & 212.0 & 64.5 & $58.4 \mathrm{ab}$ \\
\hline
\end{tabular}

${ }^{x}$ Nisan: ÖD, y Mayıs: ÖD, ${ }^{2}$ Haziran: Aynı sütundaki farklı harflerle belirtilen ortalamalar istatistiksel olarak önemlidir (P<0.05).

\section{Şakşak lokasyonunda yetiştiricilik}

Şakşak lokasyonunda yetiştirme dönemi boyunca alınan bitki başına aylık verimler Çizelge 4'de verilmiştir. Bu lokasyonda ilk ürünler Nisan ayında alınmaya başlanmış olup, hasatler temmuz ayı sonuna kadar devam etmiştir. En yüksek verimler mayıs ayından alınırken en düşük verimler nisan ayında alınmıştır. Mayıs ayında en

Çizelge 4. Şakşak lokasyonuna ait aylık verimler (g/bitki)

Table 4. Monthly yields of Şakşak location

\begin{tabular}{lcccc}
\hline \multirow{2}{*}{ Çeşit } & \multicolumn{3}{c}{ Aylar } \\
\cline { 2 - 5 } & Nisan $^{\mathrm{x}}$ & Mayıs $^{{ }}$ & Haziran $^{\mathrm{z}}$ & Temmuz $^{\mathrm{w}}$ \\
\hline Camarosa & 7.3 & 349.7 & 51.8 & 57.2 \\
Rubygem & 3.4 & 376.6 & 90.1 & 77.0 \\
Albion & 12.0 & 206.9 & 37.2 & 28.2 \\
San Andreas & 7.2 & 223.0 & 26.9 & 17.0 \\
\hline
\end{tabular}

${ }^{\mathrm{x}}$ Nisan: ÖD, ${ }^{\mathrm{y}}$ Mayıs: ÖD, ${ }^{\mathrm{z}}$ Haziran: ÖD, ${ }^{\mathrm{z}}$ Temmuz: ÖD

\section{Urumu lokasyonunda yetiştiricilik}

Urumu lokasyonunda yetiştirme dönemi boyunca alınan bitki başına aylık verimler Çizelge 5'te verilmiştir. Nisan ayında ilk verimler alınmaya başlanmıs olup, Camarosa ve Rubygem çeşitleri diğer çeşitlerden yüksek verim değerleri vermiş̧ir Mayıs ayı en yüksek verimi San yüksek verim Rubygem çeşidinden (376.6 g/bitki) elde edilmiş ve onu Camarosa çeşidi $(349.7 \mathrm{~g} / \mathrm{bitki})$ takip etmiştir. Mayıs ayındaki en düşük verimler Albion çeşidinden ( $206.9 \mathrm{~g} / \mathrm{bitki})$ elde edilmiştir. Haziran ve temmuz aylarında verimler düşmüş ve birbirine yakın bulunmuştur.

Çizelge 5. Urumu lokasyonuna ait aylık verimler (g/bitki)

Table 5. Monthly yields of Urumu location

\begin{tabular}{lccc}
\hline \multirow{2}{*}{ Çeşit } & \multicolumn{3}{c}{ Aylar } \\
\cline { 2 - 4 } & Nisan & Mayıs & Haziran \\
\hline Camarosa & 45.1 & 230.2 & 53.7 \\
Rubygem & 32.2 & 277.1 & 45.0 \\
Albion & 18.6 & 244.5 & 47.0 \\
San Andreas & 19.1 & 284.4 & 50.6 \\
\hline
\end{tabular}

${ }^{x}$ Nisan: ÖD, ${ }^{y}$ Mayıs: ÖD, ${ }^{2}$ Haziran: ÖD.

Verimin aylara dağılımı bakımından sonuçlar birlikte değerlendirildiğinde ilk ürünlerin her üç lokasyonda da nisan ayında alındığı görülmektedir. Bu ayda çeşitlerden
Andreas çeşidi ( $284.4 \mathrm{~g} /$ bitki) vermiştir. En düşük verim ise Camarosa çeşidinden (230.2 g/bitki) alınmıştır. Haziran ayında verim miktarında oldukça büyük düşüşler görülmüş olup, verim değerleri $45.0 \mathrm{~g} / \mathrm{bitki}$ (Rubygem çeşidi) ile $53.7 \mathrm{~g} /$ bitki (Camarosa çeşidi) arasında değişim göstermiştir. 
(2003), Amik Ovası koşullarında beş çilek çeşidinin (Dorit, Selva, Sweet Charlie, Camarosa ve Chandler) açıkta ve yüksek tünel altında frigo fide kullanarak iki yıl süreyle yaptıkları çalışmada ilk ürünleri mart ayında başladığını bildirmişlerdir. Çalışmamızda ilk ürünlerin nisan ayında alınması denemenin yürütüldüğü yetiştirme sezonunda havaların soğuk geçmesi ile açıklanabilir. Saraçoğlu (2013), bazı gün-nötr ve kısa gün çeşitleri kullanarak Tokat koşullarında yaptıkları çalışmada ilk ürünlerin mayıs ayında alındığını bildirmişlerdir. Dolayısı ile ekolojik farklııkların çileklerde ilk ürünlerin alınması üzerinde etkisi açıktır. En yüksek verimler Antakya lokasyonunda nisan ayında alınırken, Şakşak ve Urumu lokasyonlarında mayıs ayında elde edilmiştir. Benzer sonuçlar Gündüz (2003), tarafındanda ortaya konmuştur. Antakya ve Urumu lokasyonlarında verimler haziran ayı ortalarında tamamlanmasına karşın, Şakşak lokasyonunda temmuz ayı sonlarına kadar verim alınmaya devam edilmiştir. Derim sezonu ilerledikçe verimlerde azalmalar görülmüştür. Derim sezonu ilerledikçe verimlerde düşüşler olduğu bir çok çalışma ile ortaya konmuştur (Özdemir, 1992; Türemiş ve Kaşka 1997; Özdemir ve ark., 2001; Kafkas, 2004; Özdemir ve Gündüz, 2004; Özuygur, 2005; Gündüz ve Özdemir 2010). Ayrıca derim sezonunun son ayında (Haziran) kısa gün çeşitlerinin verimleri Antakya ve Urumu lokasyonunda gün-nötr çeşitlerin verimlerinden yaklaşık \% 50 oranında daha yüksek olduğu belirlenmiştir. Şakşak lokasyonunda ise verimlere temmuz ayında alınmaya devam edilerek haziran ayı verimi ile benzer bulunmuştur. Bu durum Şakşak lokasyonunun $(755 \mathrm{~m})$ Antakya $(117 \mathrm{~m})$ ve Urumu (443 m) lokasyonundan rakım bakımından daha yüksek dolayısı ile daha serin (Şakşak lokasyonu haziran ayı ortalama sıcaklık değeri: $19.5^{\circ} \mathrm{C}$; Antakya lokasyonu haziran ayı ortalama sıcaklık değeri: $25.9{ }^{\circ} \mathrm{C}$ ) olması ile açıklanabilir. Nitekim Kazova (Tokat) koşullarında Saraçoğlu (2013), tarafından yürütülen çalışmada kısa gün çeşitlerinde hasatlerin tamamına yakını mayıshaziran aylarında yapılırken, temmuz ağustos aylarında alınan verim değerleri toplam verimin \% 2-3'ü arasında değişmiştir. Gün-nötr çeşitlerde ise temmuz-ağustos aylarında toplam verimin \% 18-36'lık kısmının alındığını bildirmiştir. Bu durumda Akdeniz ekolojik koşullarında yüksek rakımlı lokasyonlarda yaz aylarında gün-nötr çeşitlerden bir miktar verim alınabilmesine karşın, karasal iklimin hakim olduğu yörelerde verim değerlenin oldukça uygun olduğunu söylemek mümkündür.

\section{Bitki başına toplam verimler (g/bitki)}

2014-2015 yetiştirme döneminde Antakya, Şakşak ve Urumu lokasyonlarında yetiştirilen çilek çeşitlerinin bitki başına toplam verim değerleri Çizelge $6^{\prime}$ da verilmiştir. Bitki başına toplam verim değerleri ile yapılan varyans analizleri sonucunda, çeşit ve çeşit $x$ lokasyon etkileşiminin önemli farklılık oluşturduğu lokasyonların ise tek başına verim üzerinde etki oluşturmadığı görülmüştür. Çeşitler arasında en yüksek verim Rubygem (477.9 g/bitki) ve Camarosa (423.9 g/bitki) çeşitlerinden alınmıştır. En düşük verimler ise San Andreas (321.0 g/bitki) ve Albion çeşitlerinden (280.4 $\mathrm{g} /$ bitki) alınmıştır. Çeşit x lokasyon etkileşimi açısından ise en yüksek verim Rubygem çeşidinde Şakşak lokasyonundan (547.1 g/bitki) ve Antakya lokasyonundan (532.6 g/bitki) alınmıştır. Bunu Camarosa çeşidi Antakya lokasyonu $(477.0 \mathrm{~g} / \mathrm{bitki})$ izlemiştir. En düşük verim değerleri ise Albion çeşidinde Antakya lokasyonundan ( $247.0 \mathrm{~g} / \mathrm{bitki})$ ve San Andreas çeşidi Şakşak lokasyonundan (274.1 g/bitki) elde edilmiştir. Bunun yanında San Andreas çeşidi Şakşak lokasyonu ile Albion çeşidinin yine Şakşak lokasyonundan da düşük verimler saptanmıştır.

Çizelge 6. Farklı lokasyonlara ait bitki başına toplam verimler (g/bitki)

Table 6. Total yields per plant from different locations

\begin{tabular}{lcccc}
\hline \multirow{2}{*}{ Çeşit } & \multicolumn{3}{c}{ Lokasyon $^{z}$} & Ortalama \\
\cline { 2 - 5 } & Antakya & Şakşak & Urumu & \\
\hline Camarosa & $477.0 \mathrm{ab}$ & $466.0 \mathrm{abc}$ & $329.0 \mathrm{~cd}$ & $423.9 \mathrm{~A}^{\mathrm{y}}$ \\
Rubygem & $532.6 \mathrm{a}$ & $547.1 \mathrm{a}$ & $354.3 \mathrm{bcd}$ & $477.9 \mathrm{~A}$ \\
Albion & $247.0 \mathrm{~d}$ & $284.3 \mathrm{~d}$ & $310.0 \mathrm{~cd}$ & $280.4 \mathrm{~B}$ \\
San Andreas & $334.9 \mathrm{bcd}$ & $274.1 \mathrm{~d}$ & $354.1 \mathrm{abc}$ & $321.0 \mathrm{~B}$ \\
\hline
\end{tabular}

Ortalama

$397.8^{\mathrm{x}}$

392.8

336.5

$x, \ddot{O} D,{ }^{y}$ Aynı sütundaki farklı harflerle belirtilen ortalamalar istatistiksel olarak önemlidir $(P<0.05)$

${ }^{2}$ Çeşit $x$ lokasyon etkileşimi önemli $(P<0.05)$

Sonuç olarak farklı lokasyonlarda yürütülen bu çalışmada çeşitlerden bitki başına en yüksek verimler
Rubygem ve Camarosa çeşitlerinden alınırken, en düşük verim Albion ve San Andreas çeşitlerinden elde 
edilmiştir. Camarosa ve Rubygem çeşitleri dünyada ve ülkemizde verimli olduğu bildirilen çeşitlerdir. Camarosa çeşidi sert etli olması ve yüksek verimi nedeniyle en çok yetiştiriciliği yapılan çeşit olmuştur. Ragab ve ark., (2000); Özdemir ve ark., (2001); Palha ve ark., (2002); Özdemir ve Gündüz (2004); ve Kafkas (2004) tarafından yapılan çalışmalarda Camarosa çeşidi verimli bulunmuştur. Çalışmada Rubygem çeşidi de yüksek verimli olarak bulunmuştur. Serçe ve ark., (2012), cam serada farklı fide tipi ile üç çilek çeşidi (Festival, Rubygem ve Sweet Charlie) kullanarak yaptıkları çalışamda Rubygem çeşidinin diğer çeşitlerden daha yüksek verim verdiğini bildirmişlerdir. Araştırmamızda kullanılan Albion ve San Andreas düşük verim veren çeşitler olmuştur. Bu çeşitler gün-nötr özelliğe sahip çeşitlerdir. Bu çeşitlerden düşük verim alınması gönnötr çeşitlerin Akdeniz ekolojik koşullarına adaptasyonlarının düşük olması ve lokasyonlar arasındaki bakım koşullarından kaynaklanmış olabilir. Nitekim Saraçoğlu (2013), Kazova (Tokat) koşullarında bazı gün-nötr (Fern ve Kabarla) ve kısa gün (Camarosa, Sweet Charlie, Rubygem ve Festival) çilek çeşitlerini kullarak yaptıkları çalışmada gün-nötr çeşitler kısa gün çeşitlerinden \% 42 oranında daha yüksek verim verdiklerini bildirmişlerdir. Bu durum ılıman iklimlerde gün-nötr çeşitlerin daha verimli olduğunu göstermektedir. Lokasyonların verimler üzerine etkisi değerlendirildiğinde istatistiksel olarak önemli bir farklılık bulunmamakla birlikte Antakya ve Şakşak lokasyonları Urumu lokasyonundan daha yüksek verim vermiştir (Çizelge 6). Verimli çeşitlerin (Camarosa ve Rubygem) Urumu lokasyonunda düşük verimli olmaları bu çeşitlerin soğuklanma ihtiyaçlarını tam olarak karşılayamamaları ve kültürel işlemlerin yeterli düzeyde yapılmaması ile açıklanabilir. Gündüz (2010), üç yetiştirme yerinde (Cam sera, plastik sera ve açıkta) 18 çilek çeşidini tüplü taze fide ile yetiştirerek yapmış olduğu çalışmada cam seradan düşük verim alınmasına karşın, soğuklama gereksinimi düşük olan Sweet Charlie çeşidinin veriminin oldukça iyi düzeyde olduğunu bildirmiştir. Dolayısı ile çeşitlerin soğuklanma intiyaçlarını karşılayabilecekleri ekolojik koşullarda yetiştirilmesi ile kültürel işlemlerin düzenli bir şekilde yürütülmesi verimlilik bakımından oldukça önemlidir.

ilk derimler en erken Albion ve San Andreas çeşitlerinde, lokasyonlardan Antakya'da nisan ayının ilk haftasında kaydedilmiştir. Derim süreleri çeşitler ve lokasyonlara göre 42-78 gün arasında belirlenmiştir. En uzun derim süresi Camarosa ve Rubygem lokasyonlardan ise Şakşak lokasyonundan alınmıştır. Bu sonuçlar hasat süresi üzerinde çeşit ve lokasyonun etkisini göstermektedir.
Bitki başına toplam verim bakımından en yüksek değerler Rubygem ve Camarosa çeşitlerinden elde edilmiştir. En düşük verim Albion çeşidinden alınmıştır. Camarosa ve Rubygem çeşitleri verimli olmuş ve öne çıkmıştır. Camarosa çeşidinin meyve eti sertliğinin yüksek olması, verimli ve adaptasyon yeteneğinin yüksek olması sebebiyle yetiştiriciliği yapılan çeşit olmuştur. Çalışmamızda gün-nötr özelliğe sahip çeşitler daha düşük verimli çıkmıştır. Bu çeşitlerden düşük verim alınması gön-nötr çeşitlerin Akdeniz ekolojik koşullarına adaptasyonlarının düşük olması ve lokasyonlar arasındaki iklim şartları ve bakım koşullarından kaynaklanması ile açıklanabilir. Lokasyonlar bakımından ise en yüksek verimler Antakya'dan nisan ayında alınırken, Şakşak ve Urumu lokasyonlarında mayıs ayında elde edilmiştir. Antakya ve Urumu lokasyonlarında verimler haziran ayı ortalarında tamamlanmasına karşın, Şakşak lokasyonunda temmuz ayı sonlarına kadar meyve alınmaya devam edilmiştir. Bu durum lokasyonlar arasındaki rakım ve iklim özelliklerinin farklılığı ile açıklanabilir. Aynı zamanda Akdeniz ekolojik koşullarında çilek üretim sezonu haziran ayı başlarında sonlanmaktadır. Bölgede Şakşak lokasyonun çilek üretim sezonunun uzatılması açısından önem arz etmektedir. Ekolojik farklılıklar olmasına karşın yüksek rakımlı Şakşak lokasyonunda verim bakımından günnötr çeşitlerin başarılı olduğunu söylemek zordur.

\section{ÖZET}

Amaç: Bu çalışmanın amacı, yetiştirme lokasyonlarının çilek çeşitlerinde derim süresi ve verim dağılımı üzerindeki etkilerini belirlemektir.

Yöntem ve Bulgular: Araştırma 2014-2015 yetiştirme sezonunda Mustafa Kemal Üniversitesi Ziraat Fakültesi Bahçe Bitkileri Bölümünde, Antakya (117.6 m), Şakşak (755.1 m) ve Urumu (443.5 m) lokasyonlarında dört çilek çeşidi (Camarosa, Rubygem, Albion ve San Andreas) ile yaz dikim yöntemi kullanılarak yürütülmüştür. Çalışmada ilk derim tarihleri, derim süreleri ve aylık verim dağılımı ve bitki başına toplam verimler değerlendirilmiştir.

Genel Yorum: ilk hasatler en erken Albion ve San Andreas çeşitlerinde ve Antakya lokasyonunda nisan ayının ilk haftasında kaydedilmiştir. Derim süreleri, çeşitler ve lokasyonlara göre 41.7-78.3 gün arasında değişim göstermiştir. Verimin aylara dağılımı bakımından ilk ürünlerin genotiplere göre değişmekle birlikte her üç lokasyonda da nisan ayında alındığı görülmektedirŞakşak lokasyonunda temmuz ayında ürün alınmaya devam ederken, Antakya ve Urumu 
lokasyonlarında verim alınamamıştır. Bitki başına en yüksek verim Rubygem (473.6 g/bitki) ve Camarosa (417.1 g/bitki), çeşitlerinden elde edilmiştir. En düşük verimler Albion çeşidinde (277.4 g/bitki) alınmıştır.

Çalışmanın Önemi ve Etkisi: Çilek yetiştiricilik alanlarında çeşit faktörünün oldukça önemli olduğu belirlenmiştir. Yetiştiricilik alanlarının belirlenmesinde öncelikli olarak çeşit faktörünün dikkate alınması gereklidir.

Anahtar Kelimeler: Çilek, aylık verim, lokasyon, Antakya.

\section{TEŞEKKÜR}

Bu çalışma TUBITAK_TOVAG (Project No: 1140815) tarafından desteklenen Yüksek Lisans tezinden üretilmiştir.

\section{ÇIKAR ÇATIŞMA BEYANI}

Yazar(lar) çalışma konusunda çıkar çatışmasının olmadığını beyan eder.

\section{ARAŞTIRMACILARIN KATKI ORANI BEYANI}

Yazarlar çalışmaya eşit oranda katkı sağlamış olduklarını beyan eder.

\section{KAYNAKLAR}

Anonim, (2019). Tarımsal Yapı ve Üretim. DiE, Ankara Atasay A, Türemiş N, Demirtaş I, Göktaş A, (2006) Eğirdir (Isparta) koşullarında yaz dikimi yapılan bazı çilek çeşitlerinin verim ve kalite özellikleri. II.Ulusal Üzümsü Meyveler Sempozyumu, 14-16 Eylül 2006, Tokat, s:100-105.

Gidemen F, (2003) "Amik ovası koşullarında bazı çilek çeşitlerinin gösterdikleri özellikler", Yüksek Lisans Tezi, MKÜ Fen Bilimleri Enstitüsü, 78s, Antakya.

Gülsoy E, (2003) Van ekolojik koşullarında farklı örtü altı tiplerinde bazı çilek çeşitlerinin adaptasyonu. Yüksek Lisans Tezi. Yüzüncü Yıl Üniversitesi Fen Bilimleri Enstitüsü, Van

Gündüz K, (2003) "Bazı çilek çeşitlerinin amik ovası koşullarında açıkta ve yüksek tünel altında yetiştiriciliğinin verim, kalite ve erkencilik üzerine etkileri", Yüksek Lisans Tezi, MKÜ Fen Bilimleri Enstitüsü 106s. Antakya.

Gündüz K, Özdemir E, (2010) Farklı yetiştirme yerlerinde yetiştirilen çilek genotiplerinde çiçeklenme, derim süresi ve aylık verim dağılımı, MKÜ Ziraat Fakültesi Dergisi, 25-38.

Hancock JF, (1999) "Strawberries", Cab International, Wallingfer, UK.
İslam A, Cangi R, Yılmaz C, Özgüven Al (2003) Bazı çilek çeşitlerinin ordu ekolojisine adaptasyonu üzerine araştırmalar, Ulusal Kivi ve Üzümsü Meyveler Sempozyumu, 23-25 Ekim, 217-219, Ordu.

Iştar A, Güleryüz M, Şen, SM, (1983) Erzurum koşullarında çilek yetiştiriciliği üzerine araştırmalar. Atatürk Üniversitesi Ziraat Fakültesi Dergisi, 14(3-4): 1-12, Erzurum

Kafkas E, (2004) Bazı çilek genotiplerinde aroma bileşiklerinin tayini ve aroma bileşikleri ile bazı meyve kalite kriterleri arasındaki ilişkiler" (Doktora Tezi). Çukurova Üniversitesi, Fen Bilimleri Enstitüsü, 310s, Adana.

Kaşka N, Yazgan A, Pekmezci M, Konarlı O, Yalçın O, (1979) Çileklerde değişik yaz ve kış dikim zamanlarının turfanda çilek üretimi ve verim üzerine etkileri. Türkiye Bilimsel ve Teknik Araştırma Kurumu, Tübitak Yayınları No:417, Proje No: TOAG 179: 1-75.

Kaşka N, Yıldız Al, Paydaş S, Biçici $M$, Türemiş N, Küden A, (1986) Türkiye için bazı çilek çeşitlerinin Adana'da yaz ve kış dikim sistemleriyle örtü altında yetiştiriciliğinin verim, kalite ve erkencilik üzerine etkileri, Doğa, 10(1): 84-101.

Kurnaz Ş, Çelik H, Demirsoy H, (1992) Yaz dikim yöntemiyle bazı çilek çeşitlerinin Karadeniz Bölgesine adaptasyonlarının araştırıması. Türkiye I. Ulusal Bahçe Bitkileri Kongresi, 13-16 Ekim 1992, İzmir

Özdemir E, (2003) Early production of strawberry cultivars grown under plastic house on sand-dunes, Small Fruit Review, 2(1): 81-86.

Özdemir E, Gündüz K, Bayazit S, (2001) Tüplü taze fideyle yüksek tünelde yetiştirilen bazı çilek çeşitlerinin amik ovası koşullarında verim, kalite ve erkencilik durumlarının belirlenmesi, Bahçe, 30(1-2): 65-70.

Özdemir E, Gündüz K, Gidemen F, Şehitoğlu M, (2003) Hatay ili, Amik Ovası ve Yayladağında yetiştirilen bazı çilek çeşitlerinde renklenme durumları, Bahçe 32(12): 45-51.

Özdemir E, Gündüz K, (2004) Comparison of bag and raised bed treatments for strawberry production under unheated greenhouse conditions, Journal of the American Society for Horticultural Science, 58(2), 118-122.

Özdemir E, ve Kaşka N, (1996) Çileklerde tüplü taze fide dikim zamanlarının verim, erkencilik ve kalite üzerine etkileri. Derim, 13 (1): 16-23. 
Özdemir E, (1992) "Kumul alanlarda çilek yetiştiriciliğinde erkencilik, verim ve kalite üzerine solarizasyon, fide materyali, yetiştirme ortamı ve yüksek plastik tünellerin etkileri", Ç.Ü. Fen Bilimleri Enstitüsü, Doktora Tezi, $292 \mathrm{~s}$.

Özuygur M, (2005) "Adana koşullarında bazı yerli, amerika ve avrupa kökenli çilek çeşitleri ile bazı melez çilek genotiplerinde verim, meyve kalite kriterleri ve bitki özelliklerinin belirlenmesi", (Yüksek Lisans Tezi), Çukurova Üniversitesi, Fen Bilimleri Enstitüsü, 151s, Adana.

Palha MGS, Andrade MCS, Silva MJP (2002) "The effects of different types of plant production on strawberry yield and fruit quality", Acta Horticulturae, 567(2): 515-518.

Ragab ME, El-Oksh II, El Sayed HM, (2000) "New promising cultivar and large crown diameter of transplant increased earliness, productivity and fruit quality of annual plastic-mulched strawberry", $4^{\text {th }}$ International Strawberry Symposium, Abstract, 162, Finland.

Sabancı A, Kişi Z, Ilgın M, (2007) Kahramanmaraş koşullarında yaz ve kış dikim sistemlerinin bazı çilek çeşitlerinde verim ve kalite üzerine etkileri. Türkiye V. Ulusal Bahçe Bitkileri Kongresi, 5-7 Eylül 2007, Erzurum.
Saraçoğlu O, (2013) "Bazı nötr ve kısa gün çilek çeşitlerinin Kazova koşullarında verim ve kalite performanslarının belirlenmesi“, Doktora Tezi, GÜFBE, $153 \mathrm{~s}$. Tokat

Serçe S, Özdemir E, Gündüz K, Saraçoğlu O, Kaya C, Özgen M, (2012) Bazı çilek çeşitlerinin Antakya koşullarında, cam seradaki verim ve meyve kalite özelliklerinin belirlenmesi", IV. Ulusal Üzümsü Meyveler Sempozyumu, 432-440 pp., Antalya.

Sezer L, (2010) Mardin ili Kızıltepe ilçesinde organik çilek yetiştiriciliği olanaklarının araştırılması. Yüksek Lisans Tezi. Çukurova Üniversitesi, Fen Bilimleri Enstitüsü, Bahçe Bitkileri Ana Bilim Dalı, Adana.

Staudt G, (1989) "The Species of Fragaria", The taxanomy and geographical distribution. Acta Horticulturae, 439: 55-62.

Türemiş N, Kaşka N, Kafkas S, Çömlekçioğlu N, (1997) Comparison of yield and quality of strawberry cultivars using frigo plants and fresh runners rooted in pots (1993-94 growing season), Acta Horticulturae, 439(2): 537-541.

Türemiş N, Kaşka N, (1997) Akdeniz bölgesinde erkenci çilek yetiştiriciliği. Derim, 14(1): 20-25. 